\title{
A Systematic Review and Meta-Analysis of Depression in Postnatal Women in the Case of a Low-Income Country; Ethiopia, 2020
}

Mogesie Necho ( $\square$ nechomoges2014@gmail.com )

Wollo University https://orcid.org/0000-0003-0961-7835

Merid Abadisharew

Wollo University

Research

Keywords: Postpartum depression, a low-income country, Ethiopia

Posted Date: May 4th, 2020

DOI: https://doi.org/10.21203/rs.3.rs-25403/v1

License: (c) (i) This work is licensed under a Creative Commons Attribution 4.0 International License. Read Full License 


\section{Abstract}

\section{Background}

Maternal mental health in the postpartum period is essential for the optimal development of the newborn and appropriate breastfeeding practices. Despite this, a shortage of concrete evidence exists regarding the magnitude of postpartum depression and associated factors. This meta-analysis study was therefore done to fill such a gap.

\section{Methods}

PubMed, Scopus, and EMBASE were investigated with no time limitation. A manual search for a reference list of articles was also done. Relevant data were extracted using Meta XL package and analysis was done Stata-11 meta-prop package. Heterogeneity was checked with Cochran's Qstatistics and the Higgs $\left.\right|^{2}$ test. Furthermore, sub-group and sensitivity analyses were done. Egger's test and funnel plots tests were engaged to identify publication bias.

\section{Results}

A total of 16 studies that assessed 11400 postpartum women in Ethiopia were included. The average estimated prevalence of postpartum depression was $21.9 \%$ (95\% Cl: 18.98, 24.77). The pooled prevalence of postpartum depression was higher in studies that used SRQ-20; $24.6 \%$ (95\% Cl: 18.42, 30.84) than studies that used PHQ-9; 18.9\% (95\% Cl: 11.52, 26.28). Moreover, the pooled estimated prevalence of postpartum depression was slightly higher in the southern part of Ethiopia (22.6\%) than Addis Ababa (21.2\%). Poor marital relation (pooled aOR = 3.56) (95\% Cl: $2.50,4.63)$, unplanned pregnancy (pooled aOR $=3.48)(95 \% \mathrm{Cl}: 2.18,4.79)$, previous history of depression (pooled aOR $=4.33)(95 \% \mathrm{Cl}$ : $2.26,6.59)$, poor social support (pooled aOR $=4.5)(95 \% \mathrm{Cl}: 3.34,5.56)$, domestic violence (pooled aOR $=3.77)(95 \% \mathrm{Cl}: 2.62,4.92)$, family history of mental illness (pooled $\mathrm{aOR}=4)(95 \% \mathrm{Cl}: 1.56,6.56)$, use of substance (pooled aOR $=4.67)(95 \% \mathrm{Cl}: 4.00,5.34)$, low income (pooled aOR $=2.87)(95 \% \mathrm{Cl}: 1.59,4.14)$, stressful life event (pooled aOR $=3.5)(95 \% \mathrm{Cl}: 1.39,5.87)$ and perinatal complications (pooled aOR $=3.8)(95 \% \mathrm{Cl}$ : $1.45,6.15)$ were among the associated factors for postpartum depression in Ethiopia.

\section{Conclusion}

More than one in five women was with postpartum depression and factors such as poor marital relations, history of depression, poor social support, domestic violence, unplanned pregnancy, family history of mental illness were related to it. Therefore, maternal postnatal care services should be geared to incorporate this public essential health concern.

\section{Plain English Summary}

To date evidences showed that $10-20 \%$ of postpartum women develop depressive disorders worldwide and this is much higher in low income countries like Ethiopia. Therefore it is essential to have a pooled estimated data regarding depressive symptoms and related factors in postnatal women so that initiation of early intervention would be implemented. In this meta-analysis study we incorporated 16 studies that assessed 11400 postnatal women which were obtained from a detailed search of pub-med, Scopus and EMBASE databases.

From the sixteen studies data was extracted using a meta-XL package and main meta-analysis was done with STATA-11 meta-prop-package. Since Higgs $I^{2}$ statistics was suggestive of heterogeneity between included studies, further sub-group and sensitivity analysis was done.

The pooled estimated prevalence of depression among postnatal women was high; slightly higher than 1 in 5 women in Ethiopia were with postpartum depression. This pooled estimated prevalence was higher in studies assessed with SRQ-20 than those assessed with PHQ-9. Besides, postpartum depression was higher in the southern region of the country than Addis Ababa.

We also established that poor marital relation, unplanned pregnancy, previous history of depression, poor social support and domestic violence were among the top contributing factors for depression in postnatal women in Ethiopia. Therefore, postnatal maternal care services should integrate depression in postpartum period and also it's associated factors.

\section{Background}

Women with depression in the postpartum period show manifestations like sleep disturbance, change in appetite patterns, feeling of sadness, recurrent guilty feeling, crying, low energy, and unease feelings of anxiety and suicidal ideas(1). Nowadays postpartum depression is increasingly taking a lion share in the burden of disease among women of 15 to 49 years of age (2). Globally, $10-20 \%$ of postnatal women develops depression at a point in time (3). A survey by the World Health Organization(WHO) identified that $20-40 \%$ of childbearing age women in the developing world sustained depression in the antepartum and postpartum period at a given time (4). Besides, $19 \%$ of postnatal women in low and middle-income countries $(5,6)$ and one among twenty postnatal women in Ethiopia $(7)$ develops postpartum depression.

Different studies across the world reported different prevalence rates for postpartum depression. 
A systematic review and meta-analysis study in 2018 by S Shorey et al.2018 (8) reported the worldwide estimated prevalence of postpartum depression to be $17 \%$. Besides, a study including low and middle-income countries and assessed 34 studies reported that $19.8 \%$ of postpartum women have a common mental disorder(9). Furthermore, another study that incorporated 38412 women and 23 studies in low and middle-income countries (6) reported $19.2 \%$ of women as having postpartum depression. Another systematic review and meta-analysis study in India which assessed 38 studies reported a pooled prevalence of postpartum depression to be $22 \%(10)$. Moreover, other individual studies reported earlier showed that postpartum depression was $17.6 \%$ in Portugal (11), 27.3\% in China(12), 61.4\% in Korea(13), 18.6\% in Qatar(14), 34.8\% in Iraq(15), 34\% in Jamaica(16) ,15.4\% in Turkey (17), 13.5\% and 10.3\% in Oman(18), 31.7\% in South Africa(19), and 43\% in Uganda(20).In Ethiopia, the prevalence of postpartum depression varies between $12.2-33.8 \%(21-36)$.

Poor social support(37), poverty(38), and childbirth without the presence of relatives(39), history of depression (40), and poor woman autonomy (41) from socio-demographic variables, multi-parity $(42)$, prime-parity $(43,44)$, multiple children at home $(45)$, negative attitude toward to one's pregnancy $(22,46-49)$, depression during pregnancy $(42,50)$, premarital pregnancy $(51,52)$, miscarriage $(53)$, and prenatal high anxiety $(47)$ from pregnancy and newborn related factors, alcohol use in the husband(54), intimate partner violence $(22,55,56)$, poor husbands education $(45)$,

husbands unemployment $(46,57)$, and psychiatric problems in the husband $(58)$ among husband related factors were among the associated factors for the development of postpartum depression. In the context of Ethiopia too, poor marital relation $(27,29,32,34,35,59)$, unplanned pregnancy $(21$, $22,24,27,29,32,34)$, previous history of depression $(21,27,28,34)$, domestic violence $(21,22,27,34)$, poor social support $(21,32-35)$, and family history of mental illness $(24,28,31)$ were among the documented factors responsible for the development of postpartum depression (PPD).

Postpartum depression in women has a great impact on the health of both the mother and her baby. Early discontinuation of breastfeeding (60), negative emotion and poor health care utilization (61), cognitive impairment, and behavioral defects (62), poor mother-infant bonding resulting in rejection of the infant (63), and suicidal behaviors (64) are common complications of postpartum depression. Furthermore, a community-based cross-sectional study in Ethiopia(23) revealed that maternal postnatal depression strongly affects a child's nutritional status leading to stunting and underweight as well as inappropriate complementary feeding practices of infants.

Even though maternal mental health problems in the postpartum period are much more prominent in poorly developed nations including Ethiopia, there still exists a gap in the pooled magnitude of postpartum depression and the associated factors. The objective of the present meta-analysis was, therefore (1): To determine the pooled estimated prevalence of postpartum depression among women in the postnatal period in Ethiopia and (2): To determine the pooled odds ratio of the associated factors for postpartum depression in Ethiopia.

\section{Methods}

\section{Search strategy}

Following the Preferred Reporting Items for Systematic Reviews and Meta-Analyses (PRISMA) guidelines(65), we performed both an electronic and manual search for eligible articles. Our search for electronic libraries in Scopus, PubMed, and EMBASE and manual exploration of the reference list of articles was the backbone of the current meta-analysis. In searching articles for postpartum depression among women in the postnatal period using the PubMed database, we used the coming searching terms: (Prevalence OR Epidemiology OR magnitude AND depression OR PPD OR "depressive disorder" AND mothers OR females OR women AND postpartum period AND factor OR "risk factor" OR determinant AND Ethiopia). Besides, the search for literature in EMBASE and Scopus was done per database-specific searching guidelines. Furthermore, the reference list of included studies was done and there was no specification for studies based on the study period.

\section{Eligibility criteria's}

Before the start of data refining, we stated a defining inclusion and exclusion criteria. Articles were eligible for inclusion if (1) assessed the outcome of interest among women in the postpartum period, (2) the primary outcome of interest were prevalence of postpartum depression and its associated factors, (3) design of the study was community and institution-based cross-sectional, case-control and cohort study design, (3) and (4) the study should be piloted in Ethiopia. Previously studied reviews, studies on women with an already known psychiatric problem, studies on animals, editorials, and studies reporting depression solely during pregnancy were excluded. MN and MA screened the topics and abstracts of searched articles stored in an endnote reference manager depending on the primary and prespecified eligibility criteria independently. After that, the next stage was a detailed exploration of the screened articles in the first step by the two review authors stated above independently. Any disagreement between the two authors regarding the eligibility of articles was settled through discussion in line with available logical evidence.

\section{Methods for data extraction and quality assessment}

The two declared authors (MN and MA) dig out the relevant data from the articles included in the final analysis autonomously using a standardized data extracted template. The included studies were extracted and summarized in the form of a table. Information's extracted and summarized in the table includes the author's name, publication year, study setting, study population, sample size, study design, and the assessment instrument for postpartum depression. Data from incorporated studies was extracted based on a template structured as suggested by PRISMA guidelines (65). 
The modified Newcastle-Ottawa Scale (NOS) (66) was employed for the evaluation of the quality of studies. The domains of NOS scale in assessing the quality of studies include comparability between participants, representativeness of sample and sample size, statistical quality as well as ascertainment of cases.

\section{4: Data synthesis and analysis}

In this study, we engaged a random-effect model to work out the aggregate prevalence of postpartum depression and the associated factors for postpartum depression with their $95 \%$ Cls (67). Meta-XL version 5.3 (68) was employed to extract relevant data from included studies and the STATA11 Meta-prop package (69) was implemented to work out the pooled prevalence of postpartum depression and pooled odds ratio of the associated factors for Postpartum depression. Cochran $Q$-statistics and Higgs $R$ statistics (70) were also used to diagnose heterogeneity. The $R$ statistical value of and $R$ values of zero, 25,50 , and $75 \%$ connotes absence, little, moderate, and great heterogeneity respectively $(70)$. Furthermore, subgroup analysis and sensitivity analysis tests were also done to explore the source of heterogeneity between the included studies. A funnel plot test (71) and eggers publication bias test were used to detect publication bias.

\section{Results}

\section{Identification of studies}

Our search with the pre-specified search strategies gives rise to an overall of 845 articles. Besides, 5 articles were obtained from the reference list of included articles making the total number of retrieved articles to be 850 . Of this, we removed 24 duplicated studies before the further screening. In the next stage, we excluded 789 of the articles simply by observing their titles. Therefore the leftover 37 articles had been completely inspected for eligibility of inclusion into the current systematic review and meta-analysis study nevertheless only 16 articles were tailored in the final meta-analysis since the rest 21 articles were also excluded because of varieties of methodological and technical flaws (Fig. 1).

\section{Characteristics of included studies}

In this meta-analysis, a total of sixteen studies that assessed the prevalence of postpartum depression (21-36) and fourteen studies that assessed the associated factors $(21,22,24,26-35,59)$ had been analyzed. A total of 11400 postpartum women had participated in this analysis. Region-wise, $\operatorname{six}(26,28,29,34,36,59)$, six $(22-25,32,35)$, three $(21,31,33)$, one $(27)$ and one (30) of the studies were from the southern part of Ethiopia, Amhara region, Oromia region, Addis Ababa and Tigray respectively. Of included studies three $(26,34,36)$, ten $(21-24,27,29-32,35)$, and another three $(25$, $28,33)$ utilized PHQ-9, EPDS, and SRQ-20 to asses depression in the postnatal women. Besides regarding, the design type of the study; eight (21, 23, $25,28,32-34,36)$, seven $(22,24,27,29-31,35)$ and one $(26)$ were community-based cross-sectional, institution-based cross-sectional and cohort in respective order. Besides, six of the studies $(23,25,27,28,30,34)$ employed a multi-stage sampling method during data collection. All of the studies have reported a response rate for the study $(21-36)$ (Table 1$)$. 
Table 1

Characteristics of studies on postpartum depression which are incorporated in this meta-analysis according to author first name, year of publication, setting of study, design, sample size, assessment instrument, study population and magnitude of postpartum depression and sampling methods,

\begin{tabular}{|c|c|c|c|c|c|c|c|c|c|}
\hline Author, year & $\begin{array}{l}\text { Location } \\
\text { of the } \\
\text { study }\end{array}$ & $\begin{array}{l}\text { Study } \\
\text { design }\end{array}$ & $\begin{array}{l}\text { Sample } \\
\text { size }\end{array}$ & Tool & $\begin{array}{l}\text { Study } \\
\text { population }\end{array}$ & $\begin{array}{l}\text { Depression } \\
(\%)(n)\end{array}$ & $\begin{array}{l}\text { Sampling } \\
\text { Method }\end{array}$ & $\begin{array}{l}\text { Time of } \\
\text { PPD } \\
\text { assessment }\end{array}$ & $\begin{array}{l}\text { Response } \\
\text { rate (\%) }\end{array}$ \\
\hline $\begin{array}{l}\text { Fantahun et } \\
\text { al.,2018 (1) }\end{array}$ & $\begin{array}{l}\text { Addis } \\
\text { Ababa, } \\
\text { Ethiopia }\end{array}$ & CS & 618 & $\operatorname{EPDS}(\geq 13)$ & $\begin{array}{l}\text { Postnatal } \\
\text { women }\end{array}$ & $\begin{array}{l}23.3 \\
(n=144)\end{array}$ & Multi-stage & $\begin{array}{l}\text { Up to } 6 \\
\text { weeks of } \\
\text { delivery }\end{array}$ & 97.6 \\
\hline $\begin{array}{l}\text { Toru et al.2018 } \\
\text { (2) }\end{array}$ & $\begin{array}{l}\text { Southern } \\
\text { Ethiopia }\end{array}$ & $\begin{array}{l}\text { Community } \\
\text { CS }\end{array}$ & 456 & PHQ-9 & $\begin{array}{l}\text { Postnatal } \\
\text { women }\end{array}$ & $\begin{array}{l}22.4 \\
(n=102)\end{array}$ & Multi-stage & $\begin{array}{l}\text { Up to } 12 \\
\text { months of } \\
\text { delivery }\end{array}$ & 99 \\
\hline $\begin{array}{l}\text { Abadiga,muktar } \\
2019 \text { (3) }\end{array}$ & $\begin{array}{l}\text { Oromia, } \\
\text { Ethiopia }\end{array}$ & $\begin{array}{l}\text { Community } \\
\text { CS }\end{array}$ & 287 & $\operatorname{EPDS}(\geq 10)$ & $\begin{array}{l}\text { Postnatal } \\
\text { women }\end{array}$ & $20.9(n=60)$ & $\begin{array}{l}\text { Simple } \\
\text { random }\end{array}$ & $\begin{array}{l}\text { Up to } 12 \\
\text { months of } \\
\text { delivery }\end{array}$ & 97.3 \\
\hline $\begin{array}{l}\text { Abebe et } \\
\text { al.2019 (4) }\end{array}$ & $\begin{array}{l}\text { Amhara } \\
\text { region }\end{array}$ & CS & 511 & $\operatorname{EPDS}(\geq 13)$ & $\begin{array}{l}\text { Postnatal } \\
\text { women }\end{array}$ & $22.1(n=114)$ & $\begin{array}{l}\text { Systematic } \\
\text { sampling }\end{array}$ & $\begin{array}{l}\text { Up to } 6 \\
\text { months of } \\
\text { delivery }\end{array}$ & 97.3 \\
\hline $\begin{array}{l}\text { MM Asaye et } \\
\text { al } 2020 \text { (5) }\end{array}$ & $\begin{array}{l}\text { Amhara } \\
\text { region }\end{array}$ & CS & 526 & $\operatorname{EPDS}(\geq 13)$ & $\begin{array}{l}\text { Postnatal } \\
\text { women }\end{array}$ & $25(n=129)$ & $\begin{array}{l}\text { Cluster } \\
\text { sampling }\end{array}$ & $\begin{array}{l}\text { Up to } 6 \\
\text { weeks of } \\
\text { delivery }\end{array}$ & 100 \\
\hline $\begin{array}{l}\text { Kerie et al.2018 } \\
(6)\end{array}$ & $\begin{array}{l}\text { Southern } \\
\text { Ethiopia }\end{array}$ & CS & 408 & $\operatorname{EPDS}(\geq 10)$ & $\begin{array}{l}\text { Postnatal } \\
\text { women }\end{array}$ & $\begin{array}{l}33.8 \\
(n=138)\end{array}$ & $\begin{array}{l}\text { Systematic } \\
\text { sampling }\end{array}$ & $\begin{array}{l}\text { Up to } 12 \\
\text { months of } \\
\text { delivery }\end{array}$ & 96.7 \\
\hline $\begin{array}{l}\text { Bitew et } \\
\text { al.2019 (7) }\end{array}$ & $\begin{array}{l}\text { Southern } \\
\text { Ethiopia }\end{array}$ & $\begin{array}{l}\text { Prospective } \\
\text { cohort }\end{array}$ & 1240 & PHQ-9 & $\begin{array}{l}\text { Postnatal } \\
\text { women }\end{array}$ & $22.1(n=274)$ & NA & $\begin{array}{l}4-12 \\
\text { weeks after } \\
\text { childbirth }\end{array}$ & 94.6 \\
\hline $\begin{array}{l}\text { Azale et } \\
\text { al.2018 (8) }\end{array}$ & $\begin{array}{l}\text { Southern } \\
\text { Ethiopia }\end{array}$ & $\begin{array}{l}\text { Community } \\
\text { CS }\end{array}$ & 3147 & PHQ- $9 \geq 5$ & $\begin{array}{l}\text { Postnatal } \\
\text { women }\end{array}$ & $12.2(n=385)$ & $\begin{array}{l}\text { Population } \\
\text { census }\end{array}$ & $\begin{array}{l}1 \text { up to } 12 \\
\text { months of } \\
\text { delivery }\end{array}$ & 100 \\
\hline $\begin{array}{l}\text { Anato et al } \\
.2019(9)\end{array}$ & $\begin{array}{l}\text { Amhara, } \\
\text { Ethiopia }\end{array}$ & $\begin{array}{l}\text { Community } \\
\text { CS }\end{array}$ & 232 & $\operatorname{EPDS}(\geq 13)$ & $\begin{array}{l}\text { Postnatal } \\
\text { women }\end{array}$ & $22.8(n=53)$ & Multistage & $\begin{array}{l}5-10 \\
\text { months of } \\
\text { delivery }\end{array}$ & 97.5 \\
\hline $\begin{array}{l}\text { Shewangizaw } \\
\text { et al.2018 (10) }\end{array}$ & $\begin{array}{l}\text { Harar, } \\
\text { Ethiopia }\end{array}$ & CS & 122 & EPDS & $\begin{array}{l}\text { Postnatal } \\
\text { women }\end{array}$ & $\begin{array}{l}13.11 \\
(n=16)\end{array}$ & Convenience & $\begin{array}{l}1 \text { week of } \\
\text { delivery }\end{array}$ & 100 \\
\hline $\begin{array}{l}\text { Mariam et } \\
\text { al.2016 (11) }\end{array}$ & $\begin{array}{l}\text { Tigray, } \\
\text { Ethiopia }\end{array}$ & CS & 616 & $\operatorname{EPDS}(\geq 8)$ & $\begin{array}{l}\text { Postnatal } \\
\text { women }\end{array}$ & $19(n=117)$ & Multistage & $\begin{array}{l}6 \text { weeks of } \\
\text { delivery }\end{array}$ & 97.3 \\
\hline $\begin{array}{l}\text { Shitu et } \\
\text { al.2019(12) }\end{array}$ & $\begin{array}{l}\text { Amhara, } \\
\text { Ethiopia }\end{array}$ & $\begin{array}{l}\text { Community } \\
\text { CS }\end{array}$ & 596 & $\operatorname{EPDS}(\geq 8)$ & $\begin{array}{l}\text { Postnatal } \\
\text { women }\end{array}$ & $23.7(n=141)$ & $\begin{array}{l}\text { Cluster } \\
\text { sampling }\end{array}$ & $\begin{array}{l}\text { Up to } 12 \\
\text { months of } \\
\text { delivery }\end{array}$ & 97.4 \\
\hline $\begin{array}{l}\text { W Dargie et } \\
\text { al.2020 (13) }\end{array}$ & $\begin{array}{l}\text { Amhara, } \\
\text { Ethiopia }\end{array}$ & CS & 308 & $\operatorname{EPDS}(\geq 13)$ & $\begin{array}{l}\text { Postnatal } \\
\text { women }\end{array}$ & $15.6(n=48)$ & Systematic & $\begin{array}{l}\text { Within } 6 \\
\text { weeks of } \\
\text { delivery }\end{array}$ & 100 \\
\hline $\begin{array}{l}\text { Teferra benti et } \\
\text { al.2015(14) }\end{array}$ & $\begin{array}{l}\text { Oromia } \\
\text {,Ethiopia }\end{array}$ & $\begin{array}{l}\text { Community } \\
\text { CS }\end{array}$ & 340 & $\begin{array}{l}\text { SRQ-20 } \geq \\
6\end{array}$ & $\begin{array}{l}\text { Postnatal } \\
\text { women }\end{array}$ & $31.5(n=107)$ & $\begin{array}{l}\text { Simple } \\
\text { random }\end{array}$ & $\begin{array}{l}\text { During px \& } \\
1 \text {-year after } \\
\text { birth }\end{array}$ & 95.2 \\
\hline $\begin{array}{l}\text { G gebremichael } \\
\text { et al.2018 (15) }\end{array}$ & $\begin{array}{l}\text { Southern } \\
\text { Ethiopia }\end{array}$ & $\begin{array}{l}\text { Community } \\
\text { CS }\end{array}$ & 704 & $\begin{array}{l}\text { SRQ-20 } \geq \\
6\end{array}$ & $\begin{array}{l}\text { Postnatal } \\
\text { women }\end{array}$ & $22.6(n=159)$ & Multi-stage & $\begin{array}{l}\text { 1-year after } \\
\text { birth }\end{array}$ & 96.7 \\
\hline $\begin{array}{l}\text { JN } \\
\text { baumgartner et } \\
\text { al.2014 (16) }\end{array}$ & $\begin{array}{l}\text { Amhara, } \\
\text { Ethiopia }\end{array}$ & $\begin{array}{l}\text { Community } \\
\text { CS }\end{array}$ & 1294 & $\begin{array}{l}\text { SRQ-20 } \geq \\
7\end{array}$ & $\begin{array}{l}\text { Postnatal } \\
\text { women }\end{array}$ & $19.8(n=256)$ & Multi-stage & $\begin{array}{l}\text { Within } 2 \\
\text { years of } \\
\text { delivery }\end{array}$ & 98 \\
\hline
\end{tabular}

\section{Quality of Included Studies}

In assessing the quality of included studies, we used the modified Newcastle Ottawa quality assessment as a gold standard. The quality of studies varies from 7 to 10 implying that none of the studies have poor quality. One of the studies has moderate quality(31) and the remaining fifteen were having good quality (Additional file 1). 
Sixteen studies (21-36) were incorporated to yield the pooled estimated effect size of postpartum depression. The reported magnitude of postpartum depression among the included studies ranges from $12.2 \%(36)$ to $33.8 \%$ (29). The average estimated prevalence of postpartum depression using the random effect model was $21.9 \%(95 \% \mathrm{Cl}: 18.98,24.77)$. The variation attributed between the included studies which were not due to chance was considerable $\left(I^{2}=98 \%\right.$, $p$-value $\left.=0.000\right)$ from the variance between the included studies (Fig. 2).

\section{Subgroup analysis of the prevalence of postpartum depression by the tools used to measure postpartum depression.}

Since the average effect size for the prevalence of postpartum depression was significantly influenced by the difference between the included studies, it was mandatory to conduct a subgroup analysis. Therefore, we used the measurement tools for postpartum depression to perform subgroup analysis. The subgroup analysis by assessment instrument yields that, measurement with SRQ-20 provided significantly higher result, $24.6 \%$ (95\% Cl: $18.42,30.84)$ with $\left(I^{2}=98 \%, p<0.001\right)$ than the result with $\mathrm{PHQ}-9$ which was $18.9 \%(95 \% \mathrm{Cl}: 11.52,26.28)\left(I^{2}=99 \%, \mathrm{p}<0.001\right)$ (Figure-3).

\section{Sub-group analysis of the prevalence of postpartum depression by the setting of the study.}

Although a subgroup analysis was done based on the setting where the study was done, there was no significant difference in the pooled prevalence of postpartum depression between community-based studies (22\%) and institution-based studies (21.7\%).

\section{Sub-group analysis of the prevalence of postpartum depression by the regional location of the study.}

The pooled prevalence of post-partum depression was slightly higher in studies from the southern part of Ethiopia (22.6\%) than the central region (Addis Ababa) (21.2\%) and this difference was also significant statistically $(p=0.001)$.

\section{Sensitivity analysis}

We performed a leave out a sensitivity analysis to detect the source of heterogeneity. However, our result showed that the average prevalence of postpartum depression when each study was left out from the analysis ranges from $21.08 \%(18.47,23.68)$ to $22.52 \%(20.34,24.69)$. Therefore, the result was not outweighed by the influence of a single study (Table 2). 
Table 2

A sensitivity analysis of the prevalence of postpartum depression in women at postnatal period when each indicated studies are removed at a time with its $95 \%$ confidence interval.

\begin{tabular}{|llll|}
\hline No & Study excluded & Prevalence of postpartum depression & 95\% Confidence interval \\
\hline 1 & Fantahun et al.,2018 & 21.77 & $18.69,24.86$ \\
\hline 2 & Toru et al.2018 & 21.83 & $18.77,24.90$ \\
\hline 4 & Kerie et al. 2018 & 21.08 & $18.47,23.68$ \\
\hline 5 & Aitew et al.2019 & 21.85 & $18.66,25.05$ \\
\hline 6 & G gebremichael et al.2018 & 21.82 & $20.34,24.69$ \\
\hline 7 & Abadiga,muktar 2019 & 21.93 & $18.72,24.93$ \\
\hline 8 & Teferra benti et al.2015 & 21.23 & $18.97,24.90$ \\
\hline 9 & Abebe et al.2019 & 21.85 & $18.41,24.05$ \\
\hline 10 & MM Asaye et al 2020 & 21.66 & $18.78,24.93$ \\
\hline 11 & Anato et al .2019 & 21.81 & $18.62,24.70$ \\
\hline 12 & Shitu et al.2019 & 21.75 & $18.78,24.84$ \\
\hline 13 & W Dargie et al.2020 & 22.29 & $18.67,24.82$ \\
\hline 14 & JN baumgartner et al.2014 & 21.87 & $19.29,25.29$ \\
\hline 15 & Shewangizaw et al.2018 & 22.45 & $18.98,24.77$ \\
\hline 16 & Mariam et al.2016 & 21.87 & $19.47,25.43$ \\
\hline
\end{tabular}

\section{Publication bias}

A scatter plot of the logit event rate of postpartum depression on the X-axis and its standard error on the Y-axis was done and showed that it seems as there was a publication bias since the graph was slightly asymmetrical (Fig. 4). However, the eggers publication bias test revealed that there was no significant publication bias $(B=71.2, \mathrm{SE}=44$ and $\mathrm{P}$-value $=0.13)$.

\section{Associated factors for postpartum depression in Ethiopian women}

As stated previously, fourteen studies $(21,22,24,26-35,59)$ had reported one or more factors related to the development of depression in postnatal women. Our narrative synthesis revealed that poor marital relation $(27,29,32,34,35,59)$, unplanned pregnancy $(21,22,24,27,29,32,34)$, previous history of depression $(21,27,28,34)$, domestic violence $(21,22,27,34)$, poor social support $(21,32-35)$, family history of mental illness $(24,28,31)$, use of substance $(21,27,34)$ and low income $(27,28,59)$ were among the most commonly reported factors contributing to development of postpartum depression in postnatal women( Table 3 ). 
Table 3

Characteristics of associated factors for postpartum depression in Ethiopia by their Odds ratio, Confidence interval, association strength, author and year of publication.

\begin{tabular}{|c|c|c|c|c|}
\hline Associated factors & Odds ratio(AOR) & $95 \% \mathrm{Cl}$ & Strength of association & Author, year of publication \\
\hline Being unmarried & 2.5 & $1.20,4.90$ & Strong and positive & Fantahun et al,2016 \\
\hline Income difficulty & 2.3 & $1.30,4.00$ & Strong and positive & Fantahun et al,2016 \\
\hline Death of a child & 3.2 & $1.30,8.00$ & Strong and positive & Fantahun et al,2016 \\
\hline Unplanned pregnancy & 2.9 & $1.60,5.00$ & Strong and positive & Fantahun et al,2016 \\
\hline Substance use & 4.9 & $1.10,21.30$ & Strong and positive & Fantahun et al,2016 \\
\hline Previous depression & 4.2 & $2.30,7.80$ & Strong and positive & Fantahun et al,2016 \\
\hline Domestic violence & 3.1 & $1.60,5.90$ & Strong and positive & Fantahun et al,2016 \\
\hline 18 up to 23 years age & 3.9 & $1.53,9.90$ & Strong and negative & Toru et al.2018 \\
\hline Unplanned pregnancy & 3.4 & $1.71,6.58$ & Strong and negative & Toru et al.2018 \\
\hline Sleeping problem of child & 3.7 & $1.79,7.72$ & Strong and negative & Toru et al.2018 \\
\hline Domestic violence & 2.9 & $1.72,8.79$ & Strong and negative & Toru et al.2018 \\
\hline Unsatisfied marital relation & 2.7 & $1.32,5.62$ & Strong and negative & Toru et al.2018 \\
\hline Poor social support & 4.3 & $1.79,10.60$ & Strong and negative & Toru et al.2018 \\
\hline History of depression & 7.4 & $3.12,17.35$ & Strong and negative & Toru et al.2018 \\
\hline Substance use & 5.2 & $2.52,10.60$ & Strong and negative & Toru et al.2018 \\
\hline Unplanned pregnancy & 7.8 & $3.19,19.26$ & Strong and negative & abadiga, 2019 \\
\hline Primi-parity & 4.99 & $1.54,16.09$ & Strong and negative & abadiga, 2019 \\
\hline History of depression & 3 & $1.06,8.82$ & Strong and negative & abadiga, 2019 \\
\hline Domestic violence & 5.9 & $2.44,14.40$ & Strong and negative & abadiga, 2019 \\
\hline Substance use & 3.9 & $1.52,10.30$ & Strong and negative & abadiga, 2019 \\
\hline Poor social support & 6.6 & $2.25,19.29$ & Strong and negative & abadiga, 2019 \\
\hline Stressful life event & 4.5 & $2.64,7.54$ & Strong and negative & Abebe et al.2019 \\
\hline Domestic decision making & 4.3 & $2.54,7.14$ & Strong and negative & Abebe et al.2019 \\
\hline Unplanned pregnancy & 1.9 & $1.02,3.41$ & Strong and negative & Abebe et al.2019 \\
\hline Partner violence & 3.2 & $1.76,5.67$ & Strong and negative & Abebe et al.2019 \\
\hline Hospitalization of the baby & 2.2 & $1.17,4.31$ & Strong and positive & Abebe et al.2019 \\
\hline Abortion history & 1.8 & $1,07,2.96$ & Strong and positive & MM Asaye et al 2020 \\
\hline Low birth weight of baby & 3.1 & $1.78,5.48$ & Strong and positive & MM Asaye et al 2020 \\
\hline GA of baby< 36 weeks & 2.2 & $1.22,3.88$ & Strong and positive & MM Asaye et al 2020 \\
\hline Unplanned pregnancy & 2 & $1.24,3.31$ & Strong and positive & MM Asaye et al 2020 \\
\hline Relative mental illness & 1.2 & $1.09,3.05$ & weak and positive & MM Asaye et al 2020 \\
\hline Has no ANC visit & 4.05 & $1.81,9.05$ & Strong and positive & MM Asaye et al 2020 \\
\hline Has no PNV & 1.8 & $1.11,3.00$ & strong and positive & MM Asaye et al 2020 \\
\hline Unplanned pregnancy & 4.5 & $2.31,8.71$ & Strong and positive & Kerie et al.2018 \\
\hline Age $15-24$ years & 0.4 & $0.18,0.98$ & Weak and negative & Kerie et al.2018 \\
\hline Chronic illness & 7.7 & $2.34,25.44$ & Strong and positive & Kerie et al.2018 \\
\hline Death of the infant & 4.1 & $1.78,9.51$ & Strong and positive & Kerie et al.2018 \\
\hline Unstable marriage & 6 & $2.79,12.99$ & Strong and positive & Kerie et al.2018 \\
\hline
\end{tabular}




\begin{tabular}{|c|c|c|c|c|}
\hline Intimate partner violence & $\mathrm{aRR}=1.06$ & $1.00,1.12$ & Strong and positive & Bitew et al.2019 \\
\hline Depression in pregnancy & $\mathrm{aRR}=1.3$ & $1.15,1.45$ & Strong and positive & Bitew et al.2019 \\
\hline Premature baby & 11.4 & NA & Strong and positive & Shewangizaw et al.2018 \\
\hline Poor satisfaction with care & 8.7 & NA & Strong and positive & Shewangizaw et al.2018 \\
\hline Family hx of mental illness & 7.4 & NA & Strong and positive & Shewangizaw et al.2018 \\
\hline Single/divorced/widowed & 3.5 & $1.35,8.82$ & Strong and positive & Shitu et al.2019 \\
\hline Unwanted pregnancy & 1.9 & $1.14,3.33$ & Strong and positive & Shitu et al.2019 \\
\hline Undesired infant sex & 1.8 & $1.13,2.86$ & Strong and positive & Shitu et al.2019 \\
\hline Infant illness & 2.1 & $1.30,3.34$ & Strong and positive & Shitu et al.2019 \\
\hline Poor social support & 3.2 & $1.55,6.43$ & Strong and positive & Shitu et al.2019 \\
\hline Rural residence & 2.6 & $2.56,4.19$ & Strong and positive & Azale et al.2018 \\
\hline Grand multi-parity & 2.0 & $1.22,3.26$ & Strong and positive & Azale et al.2018 \\
\hline Perinatal complications & 2.6 & $1.89,3.44$ & Strong and positive & Azale et al.2018 \\
\hline Past history of abortion & 1.5 & $1.07,2.11$ & Moderate and positive & Azale et al.2018 \\
\hline Hunger in past 1 month & 2.4 & $1.75,3.23$ & Strong and positive & Azale et al.2018 \\
\hline Lower perceived wealth & 2.1 & $1.19,3.76$ & Strong and positive & Azale et al.2018 \\
\hline Poor marital relation(12) & 2.5 & $1.79,3.42$ & Strong and positive & Azale et al.2018 \\
\hline stressful event in past & 2.4 & $1.82,3.06$ & Strong and positive & Azale et al.2018 \\
\hline Being widowed & 4.2 & $1.14,15.20$ & Strong and positive & Wubetu et al.2020 \\
\hline Poor social support & 5.1 & $1.00,26.18$ & Strong and positive & Wubetu et al.2020 \\
\hline Hospitalization of a child & 3.3 & $1.39,7.93$ & Strong and positive & Wubetu et al.2020 \\
\hline Death of family member & 2.9 & $1.101,8.50$ & Strong and positive & Wubetu et al.2020 \\
\hline Have no death of one's child & 0.3 & $0.11,0.86$ & Strong and Negative & Teferra et al.2015 \\
\hline Poor support from family & 3.3 & $1.11,9.52$ & Strong and positive & Teferra et al.2015 \\
\hline Low income & 4.2 & $1.90,9.30$ & Strong and positive & G Gebremichael et al.2018 \\
\hline Pregnancy complications & 5 & $2.50,10.40$ & Strong and positive & G Gebremichael et al.2018 \\
\hline Smoking in husband & 4.1 & $1.60,10.60$ & Strong and positive & G Gebremichael et al.2018 \\
\hline Previous depression & 2.7 & $1.54,4.80$ & Strong and positive & G Gebremichael et al.2018 \\
\hline Family hx of psychiatry illness & 3.6 & $1.40,9.10$ & Strong and positive & G Gebremichael et al.2018 \\
\hline
\end{tabular}

The pooled odds ratio of the poor marital relationship among the above-mentioned studies was 3.56 (95\% Cl: 2.50, 4.63) (Fig. 5). This implied that women with poor marital relationships were 3.56 times at higher risk of developing PPD than women who good marital relationships. Also, the pooled odds ratio for unplanned pregnancy for the nine studies reported above was found to be 3.48 (95\% Cl: 2.18, 4.79) (Fig. 6). This showed that women who gave birth from an unplanned pregnancy were 3.5 times more likely to be depressed than women with a planned pregnancy. The previous history of depression was also an associated factor for the development of PPD with a pooled estimate odds ratio of 4.33 (95\% Cl: 2.26 , $6.59) ;(21,27,28,34)$. Besides domestic violence and poor social support were also having a significant association with the development of PPD with the estimated pooled odds ratio of 3.77 ( $95 \% \mathrm{Cl}: 2.62,4.92)(21,22,27,34), 4.5(95 \% \mathrm{Cl}: 3.34,5.56)(21,32-35)$ respectively.

Furthermore, the pooled odds ratio of family history of mental illness $(24,28,31)$, use of substance $(21,27,34)$ and low income $(27,28,59)$, stressful life event $(22,59)$ and perinatal complications $(28,59)$ was 4 (95\% Cl:1.56, 6.56), 4.67(95\% Cl:4.00, 5.34), 2.87 (95\% Cl: 1.59, 4.14), 3.5 (95\% Cl: 1.39 , 5.87 ) and 3.8 ( $95 \% \mathrm{Cl}: 1.45,6.15)$ respectively (Table 4 ). 
Table 4

Pooled estimate of the associated factors for postpartum depression in Ethiopia.

\begin{tabular}{|c|c|c|c|c|}
\hline Associated factors & Odds ratio(AOR) & $\begin{array}{l}95 \% \text { confidence } \\
\text { interval }\end{array}$ & $\begin{array}{l}\text { Strength of } \\
\text { association }\end{array}$ & $\begin{array}{l}\text { Author, year of } \\
\text { publication }\end{array}$ \\
\hline Perinatal complications & 2.6 & $1.89,3.44$ & $\begin{array}{l}\text { Strong and } \\
\text { positive }\end{array}$ & Azale et al.2018 \\
\hline Past history of abortion & 1.5 & $1.07,2.11$ & $\begin{array}{l}\text { Moderate and } \\
\text { positive }\end{array}$ & Azale et al.2018 \\
\hline Hunger in past 1 month & 2.4 & $1.75,3.23$ & $\begin{array}{l}\text { Strong and } \\
\text { positive }\end{array}$ & Azale et al.2018 \\
\hline Lower perceived wealth & 2.1 & $1.19,3.76$ & $\begin{array}{l}\text { Strong and } \\
\text { positive }\end{array}$ & Azale et al.2018 \\
\hline Poor marital relation(12) & 2.5 & $1.79,3.42$ & $\begin{array}{l}\text { Strong and } \\
\text { positive }\end{array}$ & Azale et al.2018 \\
\hline stressful event in past & 2.4 & $1.82,3.06$ & $\begin{array}{l}\text { Strong and } \\
\text { positive }\end{array}$ & Azale et al.2018 \\
\hline Being widowed & 4.2 & $1.14,15.20$ & $\begin{array}{l}\text { Strong and } \\
\text { positive }\end{array}$ & Wubetu et al.2020 \\
\hline Poor social support & 5.1 & $1.00,26.18$ & $\begin{array}{l}\text { Strong and } \\
\text { positive }\end{array}$ & Wubetu et al.2020 \\
\hline Hospitalization of a child & 3.3 & $1.39,7.93$ & $\begin{array}{l}\text { Strong and } \\
\text { positive }\end{array}$ & Wubetu et al.2020 \\
\hline Death of family member & 2.9 & $1.101,8.50$ & $\begin{array}{l}\text { Strong and } \\
\text { positive }\end{array}$ & Wubetu et al.2020 \\
\hline $\begin{array}{l}\text { Have no death of one's } \\
\text { child }\end{array}$ & 0.3 & $0.11,0.86$ & $\begin{array}{l}\text { Strong and } \\
\text { Negative }\end{array}$ & Teferra et al.2015 \\
\hline Poor support from family & 3.3 & $1.11,9.52$ & $\begin{array}{l}\text { Strong and } \\
\text { positive }\end{array}$ & Teferra et al.2015 \\
\hline Low income & 4.2 & $1.90,9.30$ & $\begin{array}{l}\text { Strong and } \\
\text { positive }\end{array}$ & $\begin{array}{l}\text { G Gebremichael et } \\
\text { al.2018 }\end{array}$ \\
\hline Pregnancy complications & 5 & $2.50,10.40$ & $\begin{array}{l}\text { Strong and } \\
\text { positive }\end{array}$ & $\begin{array}{l}\text { G Gebremichael et } \\
\text { al.2018 }\end{array}$ \\
\hline Smoking in husband & 4.1 & $1.60,10.60$ & $\begin{array}{l}\text { Strong and } \\
\text { positive }\end{array}$ & $\begin{array}{l}\text { G Gebremichael et } \\
\text { al.2018 }\end{array}$ \\
\hline Previous depression & 2.7 & $1.54,4.80$ & $\begin{array}{l}\text { Strong and } \\
\text { positive }\end{array}$ & $\begin{array}{l}\text { G Gebremichael et } \\
\text { al.2018 }\end{array}$ \\
\hline $\begin{array}{l}\text { Family hx of psychiatry } \\
\text { illness }\end{array}$ & 3.6 & $1.40,9.10$ & $\begin{array}{l}\text { Strong and } \\
\text { positive }\end{array}$ & $\begin{array}{l}\text { G Gebremichael et } \\
\text { al.2018 }\end{array}$ \\
\hline Associated factors & Risk groups & $\begin{array}{l}\text { Pooled effect size\& } \\
95 \% \mathrm{Cl}\end{array}$ & $\left.\right|^{2}$ & Studies pooled \\
\hline Unplanned pregnancy & Women who have unplanned pregnancy & $3.48(2.18,4.79)$ & $90 \%$ & $(1-6,12)$ \\
\hline $\begin{array}{l}\text { Previous history of } \\
\text { depression }\end{array}$ & Women having history of depression & $4.33(2.26,6.59)$ & $94 \%$ & $(1-3,15)$ \\
\hline Poor social support & Women with poor social support & $4.5(3.34,5.56)$ & $96 \%$ & $(2,3,12-14)$ \\
\hline Domestic violence & Women who faced domestic violence & $3.77(2.62,4.92)$ & $94.6 \%$ & $(1-4)$ \\
\hline Poor marital relation & $\begin{array}{l}\text { Single/divorced/widowed\& dissatisfied } \\
\text { marriage }\end{array}$ & $3.74(2.47,5.00)$ & $92 \%$ & $(1,2,6,12,13,17)$ \\
\hline Substance use & Those women who are using substances & $4.67(4.00,5.34)$ & $90.6 \%$ & $(1-3)$ \\
\hline Low income & Women with insufficient income & $2.87(1.59,4.14)$ & $84 \%$ & $(1,15,17)$ \\
\hline $\begin{array}{l}\text { Family history of mental } \\
\text { illness }\end{array}$ & $\begin{array}{l}\text { Women with history of mental illness in } \\
\text { the family }\end{array}$ & $4(1.56,6.56)$ & $92.6 \%$ & $(5,10,15)$ \\
\hline Stressful life-event & Women who faced stressful event & $3.5(1.39,5.87)$ & $97 \%$ & $(4,17)$ \\
\hline Perinatal complications & Women with perinatal complications & $3.8(1.45,6.15)$ & $98 \%$ & $(15,17)$ \\
\hline
\end{tabular}




\section{Discussion}

To date, this review and meta-analysis on depression and the related factors in women in the postnatal period are the first of its kind in the context of Ethiopia. Therefore, the pooled effect size of postpartum depression and related factors would add a body for the scientific community and other diverse stakeholders who are intended to intervene in this significant public health issue. We gathered data from a total of 11400 postpartum women and a total of sixteen studies from both institutional and community settings and the estimated pooled prevalence of postpartum depression were $21.9 \%$ (95\% Cl: $18.98,24.77)$.

The result of the pooled estimated prevalence of postpartum depression in this study $(21.9 \%)$ was in line with a systematic review and meta-analysis of depression in the postpartum period in India (22\%) which analyzed 38 studies and 20043 women(10). It was also consistent with the result of a systematic review and meta-analysis study in women from low and middle-income countries which assessed 34 studies and $19.8 \%$ were having a postpartum common mental disorder(9). Furthermore, another study that incorporated 38412 women and 23 studies in low and middle-income countries (6) reported $19.2 \%$ of women as having postpartum depression which was also supportive of the current finding.

However, the result of the pooled estimated prevalence of postpartum depression in Ethiopia exceeds the worldwide estimated prevalence of postpartum depression; 17\% reported in 2018 by S Shorey et al.2018 (8). The possible reason for the higher estimated prevalence in the earlier study as compared to our study could be due to the inclusion of a larger number of studies and participants in the included studies in the analysis ( 26 cross-sectional, 30 prospective cohort and 2 case-control studies with an overall of 58 studies and 37294 participants) but only 16 studies in our study. Moreover, women in the previous study were healthy subjects having no history of depression previously but our study found that a previous history of depression was among the factors responsible for the increased prevalence of postpartum depression. Moreover, our study was higher than the result of a systematic review and meta-analysis study in 11 high-income countries reported in 2005 in which the pooled estimated prevalence of postpartum depression was $12.9 \%(72)$.

Possible grounds for the difference could be due to a long time gap between the previous study and the present study. The difference in the time point for the assessment of postpartum depression could also bring the difference. The previous study includes studies that screened PPD only in the three months of the postpartum period but in the present study assessment period was far beyond this. Moreover, a socio-economic and cultural difference between high-income study subjects of the earlier study and low-income study subjects of the present study could happen and sources the variation.

Contrary to the subgroup analysis result of a worldwide meta-analysis study (8) that obtained that the pooled estimated prevalence of postpartum depression to be similar across the different measurement tools for PPD, the present study revealed that pooled prevalence of postpartum depression was higher in studies as measured with SRQ-20 (24.6\%) (95\% Cl: 18.42, 30.84) than the result with PHQ-9 (18.9\%) $(95 \%$ Cl: 11.52 , 26.28). This could be because most studies that utilized SRQ-20 delineated a lower cut off point ( $(R R Q-20$ score $\geq 6$ ) which might result in overestimation of postpartum depression.

In line with the result of an earlier meta-analysis study (8), the pooled estimated size of postpartum depression showed a geographical difference. The pooled estimated post-partum depression was slightly higher in studies from the southern part of Ethiopia (22.6\%) than the central region (Addis Ababa) (21.2\%) which could be due to the relatively improved socio-economic and cultural advances in the central region of Ethiopia. This was however in contrary to the result of a meta-analysis in India(10).

However, no significant variation in the magnitude of PPD was noticed between the community and institutional settings of the studies. This was consistent with a review and meta-analysis study in India(10) in which little but insignificant variation was observed across the community and institutional setting studies.

Regarding the associated factors of postpartum depression, fourteen studies $(21,22,24,26-35,59)$ had reported different factors and poor marital relation $(27,29,32,34,35,59)$, unplanned pregnancy $(21,22,24,27,29,32,34)$, previous history of depression $(21,27,28,34)$, domestic violence $(21$, $22,27,34)$, poor social support $(21,32-35)$, family history of mental illness $(24,28,31)$, use of substance $(21,27,34)$ and low income $(27,28,59)$ were among the most commonly reported factors.

The pooled odds ratio of the poor marital relationship among the above-mentioned studies was 3.56 that implies women with poor marital relationships were 3.56 times at higher risk of developing PPD than women who good marital relationships. A meta-analysis study in India has a similar conclusion supporting this(10). The possible reason for this could be poor marital relationship increasing the burden of psycho-social responsibility of child care and other household responsibility in the postpartum period as compared to the shared psychosocial responsibility in women which good marital relation.

Besides, the pooled odds ratio for unplanned pregnancy for the nine studies reported above was found to be 3.48. This showed that women who gave birth from an unplanned pregnancy were 3.5 times more likely to be depressed than women with a planned pregnancy. A consistent finding was reported in studies in turkey (17), Qatar (14), northwestern Brazil (73), and Iran (74). The possible reason for this could be the absence of psychological readiness in mothers with unplanned pregnancy predisposing them to be vulnerable to physiological, psycho-social challenges of pregnancy and the postpartum period. 
The previous history of depression $(21,27,28,34)$ and stressful life events $(22,59)$ was also an associated factor for the development of PPD with a pooled estimate odds ratio of 4.33 and 3.5 respectively. A consistent finding was observed in an Indian meta-analysis study(10). Furthermore, other several studies $(6,75,76)$ reported that the presence of depression during pregnancy, facing stressful life events during pregnancy, and prior history of depression as related to postpartum depression which was also in line with the current study.

Besides domestic violence was also having a significant association with the development of PPD with the estimated pooled odds ratio of 3.77 (21, $22,27,34)$. A report by world health organization in 2013 (77) suggested a similar conclusion in that intimate partner violence in women predisposes to various mental health problems in the postpartum period.

Poor social support with a pooled odds ratio of $4.5(21,32-35)$ also increases the vulnerability of postpartum depression. This was also supporting the findings of the Indian review study(10). Multiple earlier studies also reported that good interpersonal relationships across the social support networks increase flexibility to stress and subsidize enormously women from developing postpartum depression (78-81) hence decreasing the risk of Postpartum depression. A study in Ghana on interventions for women with postpartum depression revealed that psychosocial support interventions are the most effective treatments implying an underling psychosocial deficit in this target population(82).

Furthermore, the pooled odds ratio of family history of mental illness $(24,28,31)$, use of a substance $(21,27,34)$ and low income $(27,28,59)$ and perinatal complications $(28,59)$ was $4,4.67,2.87,3.5$ and 3.8 respectively. A systematic review and meta-analysis study in which 17 articles were reviewed and postpartum depression between 3 and 52 weeks postpartum periods were assessed (83) reported that substance use as a contributing factor for postpartum depression in line with the current study.

\section{Strengths And Limitations}

To start with the strength, this study utilized a prespecified search strategy through the mentioned libraries that are intended to reduce the assessor's bias. The subsequent strength was that the independent extraction of data and quality assessment of the included studies by two autonomous reviewers also lessen the reviewer's bias. Furthermore, the employment of subgroup analysis and sensitivity analysis to distinguish the foundation of heterogeneity was also strength. On the opposing side, the limits of this meta-analysis study emanate from the presence of a high difference between the included studies that might upset the deduction of the study results. Besides, the use of two or three studies in the sub-group analysis might diminish the soundness of estimate.

\section{Conclusion}

This review and meta-analysis study obtained a high pooled estimated prevalence of postpartum depression (21.9\%) suggesting that more than one in five women were having postpartum depression. The pooled estimate of postpartum depression was higher in studies that used SRQ-20 (24.6\%) than studies that used PHQ-9 (18.9\%. Moreover, the pooled prevalence of postpartum depression was slightly higher in the southern part of Ethiopia (22.6\%) than Addis Ababa (21.2\%). However, no significant difference in pooled prevalence was noticed across study settings (community versus Institutional). Poor marital relations, unplanned pregnancy, previous history of depression, poor social support, domestic violence, family history of mental illness, use of the substance, low income, stressful life event, and perinatal complications were among the associated factors for postpartum depression. Therefore, postnatal antenatal care services should integrate this significant mental health problem of women and its associated factors basically by delivering integrated postnatal care services for women.

\section{Abbreviations}

AOR: Adjusted Odds Ratio, Cl:Confidence Interval, CS:Cross-Sectional, EPDS:Edinburgh Postnatal Depression Scale, OR:Odds Ratio, PHQ-9:Patient Health Questionnaire-9, PPD:Postpartum depression, PRISMA-P:Preferred Reporting Items for Systematic Reviews and Meta-analysis, SRQ-20:Self Reporting Questionnaire-20.

\section{Declarations}

\section{Ethics approval and consent to participate}

Not applicable

\section{Consent for publication}

Not applicable

\section{Availability of Data and Materials}


All relevant data concerning this systematic review and meta-analysis study is incorporated in the manuscript.

\section{Competing Interests}

We authors have no competing interests for this meta-analysis study.

\section{Funding}

The cost afforded for this research work was covered by the authors themselves.

\section{Authors' Contributions}

MN premeditated the review idea on the prevalence and associated factors of postpartum depression in Ethiopia and defined the search strategies and manages the analysis of the research. MN and MA extracted the relevant data from included articles. Both authors participated in the quality assessment of included studies. MN writes the manuscript first draft and both of the authors revised and approved the final version of the manuscript.

\section{Acknowledgment}

We acknowledge the authors of included studies for their original contribution.

\section{Authors Information}

Mogesie Necho, Lecturer at Wollo University, College of Medicine and Health Sciences, Dessie, Ethiopia; Email: nechomoges2014@gmail.com Merid Abadisharew, Lecturer at Wollo University, College of social science and humanities, Department of sociology, Ethiopia; Email:Meridabadisharew@gmail.com

\section{References}

1. Coast E, Leone T, Hirose A, Jones E. Poverty and postnatal depression: a systematic mapping of the evidence from low and lower middle income countries. Health Place. 2012;18(5):1188-97.

2. Edition F. Diagnostic and statistical manual of mental disorders. Arlington: American Psychiatric Publishing; 2013.

3. Salem MN, Thabet MN, Fouly H, Abbas AM. Factors affecting the occurrence of postpartum depression among puerperal women in Sohag city, Egypt. Proceedings in Obstetrics and Gynecology. 2017;7(1):1-10.

4. Khalifa DS, Glavin K, Bjertness E, Lien L. Postnatal depression among Sudanese women: prevalence and validation of the Edinburgh Postnatal Depression Scale at 3 months postpartum. International journal of women's health. 2015;7:677.

5. Parsons CE, Young KS, Rochat TJ, Kringelbach ML, Stein A. Postnatal depression and its effects on child development: a review of evidence from low-and middle-income countries. British medical bulletin. 2012;101(1):57.

6. Gelaye B, Rondon MB, Araya R, Williams MA. Epidemiology of maternal depression, risk factors, and child outcomes in low-income and middleincome countries. The Lancet Psychiatry. 2016;3(10):973-82.

7. Wynaden D. There is no health without mental health: Are we educating Australian nurses to care for the health consumer of the 21 st century? International Journal of Mental Health Nursing. 2010;19(3):203-9.

8. Shorey S, Chee CYI, Ng ED, Chan YH, San Tam WW, Chong YS. Prevalence and incidence of postpartum depression among healthy mothers: a systematic review and meta-analysis. J Psychiatr Res. 2018;104:235-48.

9. Fisher J, Mello MCd, Patel V, Rahman A, Tran T, Holton S, et al. Prevalence and determinants of common perinatal mental disorders in women in low-and lower-middle-income countries: a systematic review. Bull World Health Organ. 2012;90:139-49.

10. Upadhyay RP, Chowdhury R, Salehi A, Sarkar K, Singh SK, Sinha B, et al. Postpartum depression in India: a systematic review and meta-analysis. Bull World Health Organ. 2017;95(10):706.

11. Figueiredo B, Pacheco A, Costa R. Depression during pregnancy and the postpartum period in adolescent and adult Portuguese mothers. Arch Women Ment Health. 2007;10(3):103-9.

12. Zhang Y, Zou S, Cao Y, Zhang Y. Relationship between domestic violence and postnatal depression among pregnant Chinese women. International Journal of Gynecology Obstetrics. 2012;116(1):26-30. 
13. Park J-h, Karmaus W, Zhang H. Prevalence of and risk factors for depressive symptoms in Korean women throughout pregnancy and the postpartum period. Asian nursing research. 2015;9(3):219-25.

14. Bener A, Gerber LM, Sheikh J. Prevalence of psychiatric disorders and associated risk factors in women during their postpartum period: a major public health problem and global comparison. International journal of women's health. 2012;4:191.

15. Abdollahi F, Lye M-S, Zain AM, Ghazali SS, Zarghami M. Postnatal depression and its associated factors in women from different cultures. Iranian journal of psychiatry behavioral sciences. 2011;5(2):5.

16. Wishart J, Parshad O, Kulkarni S. Prevalence of pre-and postpartum depression in Jamaican women. BMC Pregnancy Childbirth. $2005 ; 5(1): 15$.

17. Turkcapar AF, Kadıoğlu N, Aslan E, Tunc S, Zayıfoğlu M, Mollamahmutoğlu L. Sociodemographic, and clinical features of postpartum depression among Turkish women: a prospective study. BMC Pregnancy Childbirth. 2015;15(1):108.

18. Al Hinai FI, Al Hinai SS. Prospective study on prevalence and risk factors of postpartum depression in Al-Dakhla governorate in Oman. Oman medical journal. 2014;29(3):198.

19. Hung KJ, Tomlinson M, le Roux IM, Dewing S, Chopra M, Tsai AC. Community-based prenatal screening for postpartum depression in a South African township. International Journal of Gynecology Obstetrics. 2014;126(1):74-7.

20. Kakyo TA, Muliira JK, Mbalinda SN, Kizza IB, Muliira RS. Factors associated with depressive symptoms among postpartum mothers in a rural district in Uganda. Midwifery. 2012;28(3):374-9.

21. Abadiga M. Magnitude and associated factors of postpartum depression among women in Nekemte town, East Wollega zone, west Ethiopia, 2019: A community-based study. PloS one. 2019;14(11).

22. Abebe A, Tesfaw G, Mulat H, Hibdye G. Postpartum depression and associated factors among mothers in Bahir Dar Town, Northwest Ethiopia. Annals of general psychiatry. 2019;18(1):19.

23. Anato A, Baye K, Tafese Z, Stoecker BJ. Maternal depression is associated with child undernutrition: A cross-sectional study in Ethiopia. Maternal \& Child Nutrition. 2019:e12934.

24. Asaye MM, Muche HA, Zelalem ED. Prevalence and Predictors of Postpartum Depression: Northwest Ethiopia. Psychiatry Journal. $2020 ; 2020$.

25. Baumgartner JN, Parcesepe A, Mekuria YG, Abitew DB, Gebeyehu W, Okello F, et al. Maternal mental health in the Amhara region, Ethiopia: a cross-sectional survey. Global Health: Science Practice. 2014;2(4):482-6.

26. Bitew T, Hanlon C, Kebede E, Honikman S, Fekadu A. Antenatal depressive symptoms and perinatal complications: a prospective study in rural Ethiopia. BMC Psychiatry. 2017;17(1):301.

27. Fantahun A, Cherie A, Deribe L. Prevalence and Factors Associated with Postpartum Depression Among Mothers Attending Public Health Centers of Addis Ababa, Ethiopia, 2016. Clinical practice and epidemiology in mental health: CP \& EMH. 2018;14:196.

28. Gebremichael G, Yihune M, Ajema D, Haftu D, Gedamu G. Perinatal Depression and Associated Factors among Mothers in Southern Ethiopia: Evidence from Arba Minch Zuria Health and Demographic Surveillance Site. Psychiatry journal. 2018;2018.

29. Kerie S, Menberu M, Niguse W. Prevalence and associated factors of postpartum depression in Southwest, Ethiopia, 2017: a cross-sectional study. BMC Res Notes. 2018;11(1):623.

30. Mariam D, Dessalegn B, Tadesse Z, Siyoum D. Assessment of prevalence and associated factors of postpartum depression among postpartum mothers in Eastern zone of Tigray. Eur J Pharm Med Res. 2016;10(3):54-60.

31. Shewangzaw1a A, Tadesse B, Ashani T, Misgana T, Shewasinad S. Prevalence of Postpartum Depression and Associated Factors among Postnatal Women Attending At Hiwot Fana Specialized University Hospital, Harar, East Ethiopia.

32. Shitu S, Geda B, Dheresa M. Postpartum depression and associated factors among mothers who gave birth in the last twelve months in Ankesha district, Awi zone, North West Ethiopia. BMC Pregnancy Childbirth. 2019;19(1):435.

33. Tefera TB, Erena AN, Kuti KA, Hussen MA. Perinatal depression and associated factors among reproductive-aged group women at Goba and Robe Town of Bale Zone, Oromia Region, South East Ethiopia. Maternal health, neonatology, and perinatology. 2015;1(1):12.

34. Toru T, Chemir F, Anand S. Magnitude of postpartum depression and associated factors among women in Mizan Aman town, Bench Maji zone, Southwest Ethiopia. BMC Pregnancy Childbirth. 2018;18(1):442.

35. Wubetu AD, Engidaw NA, Gizachew KD. Prevalence of postpartum depression and associated factors among postnatal care attendees in Debre Berhan, Ethiopia, 2018. BMC Pregnancy and Childbirth. 2020;20(1):1-9.

36. Azale T, Fekadu A, Medhin G, Hanlon C. Coping strategies of women with postpartum depression symptoms in rural Ethiopia: a cross-sectional community study. BMC Psychiatry. 2018;18(1):41.

37. Hamdan A, Tamim H. Psychosocial risk and protective factors for postpartum depression in the United Arab Emirates. Arch Women Ment Health. $2011 ; 14(2): 125-33$.

38. Khalifa DS, Glavin K, Bjertness E, Lien L. Determinants of postnatal depression in Sudanese women at 3 months postpartum: a cross-sectional study. BMJ Open. 2016;6(3):e009443.

39. Islam MJ, Broidy L, Baird K, Mazerolle P. Intimate partner violence around the time of pregnancy and postpartum depression: The experience of women of Bangladesh. PloS one. 2017;12(5):e0176211.

Page $14 / 22$ 
40. Wright N, Hill J, Pickles A, Sharp H. The specific role of relationship life events in the onset of depression during pregnancy and the postpartum. PloS one. 2015;10(12):e0144131.

41. Stewart DE, Vigod S. Postpartum depression. N Engl J Med. 2016;375(22):2177-86.

42. DØRHEIM HO-YEN S, Tschudi Bondevik G, Eberhard-Gran M, Bjorvatn B. Factors associated with depressive symptoms among postnatal women in Nepal. Acta obstetricia et Gynecologica Scandinavica. 2007;86(3):291-7.

43. Akman C, Uguz F, Kaya N. Postpartum-onset major depression is associated with personality disorders. Compr Psychiatr. 2007;48(4):343-7.

44. Taniguchi H, Baruffi G. Childbirth overseas: the experience of Japanese women in Hawaii. Nurs Health Sci. 2007;9(2):90-5.

45. Rahman A, Creed F. Outcome of prenatal depression and risk factors associated with persistence in the first postnatal year: Prospective study from Rawalpindi. Pakistan Journal of affective disorders. 2007;100(1-3):115-21.

46. Andajani-Sutjahjo S, Manderson L, Astbury J. Complex emotions, complex problems: understanding the experiences of perinatal depression among new mothers in urban Indonesia. Culture medicine psychiatry. 2007;31(1):101-22.

47. Sayil M, Güre A, Uçanok Z. First-time mothers' anxiety and depressive symptoms across the transition to motherhood: associations with maternal and environmental characteristics. Women Health. 2007;44(3):61-77.

48. Limlomwongse N, Liabsuetrakul T. Cohort study of depressive moods in Thai women during late pregnancy and 6-8 weeks of postpartum using the Edinburgh Postnatal Depression Scale (EPDS). Arch Women Ment Health. 2006;9(3):131-8.

49. Schwab-Reese LM, Ramirez M, Ashida S, Peek-Asa C. Psychosocial employment characteristics and postpartum maternal mental health symptoms. Am J Ind Med. 2017;60(1):109-20.

50. Dindar I, Erdogan S. Screening of Turkish women for postpartum depression within the first postpartum year: the risk profile of a community sample. Public Health Nurs. 2007;24(2):176-83.

51. Alexander M, Garda L, Kanade S, Jejeebhoy S, Ganatra B. Correlates of premarital relationships among unmarried youth in Pune district, Maharashtra, India. International Family Planning Perspectives. 2007:150-9.

52. Somrongthong R, Panuwatsuk P, Amarathithada D, Chaipayom O, Sitthi-amorn C. Sexual behaviors and opinions on the sexuality of adolescents in a slum community in Bangkok. Southeast Asian journal of tropical medicine public health. 2003;34(2):443-6.

53. Acharya DR, Bell JS, Simkhada P, Van Teijlingen ER, Regmi PR. Women's autonomy in household decision-making: a demographic study in Nepal. Reproductive health. 2010;7(1):15.

54. Goyal D, Murphy SO, Cohen J. Immigrant Asian Indian women and postpartum depression. Journal of Obstetric Gynecologic Neonatal Nursing. 2006;35(1):98-104.

55. Ludermir AB, Valongueiro S, Araújo TVBd. Common mental disorders and intimate partner violence in pregnancy. Revista de saude publica. 2014;48:29-35.

56. Mendonça MFSd, Ludermir AB. Intimate partner violence and incidence of common mental disorder. Revista de Saude public. $2017 ; 51: 32$.

57. Aydin N, Inandi T, Karabulut N. Depression and associated factors among women within their first postnatal year in Erzurum province in eastern Turkey. Women Health. 2005;41(2):1-12.

58. Danaci AE, Dinç G, Deveci A, Şen FS, İçelli İ. Postnatal depression in Turkey: epidemiological and cultural aspects. Soc Psychiatry Psychiatr Epidemiol. 2002;37(3):125-9.

59. Azale T, Fekadu A, Hanlon C. Postpartum depressive symptoms in the context of high social adversity and reproductive health threats: a population-based study. International journal of mental health systems. 2018;12(1):42.

60. Field T. Postpartum depression effects on early interactions, parenting, and safety practices: a review. Infant Behavior Development. 2010;33(1):1-6.

61. Feldman R, Granat A, Pariente C, Kanety H, Kuint J, Gilboa-Schechtman E. Maternal depression and anxiety across the postpartum year and infant social engagement, fear regulation, and stress reactivity. Journal of the American Academy of Child Adolescent Psychiatry. 2009;48(9):919-27.

62. Grace SL, Evindar A, Stewart D. The effect of postpartum depression on child cognitive development and behavior: a review and critical analysis of the literature. Archives of women's mental health. 2003;6(4):263-74.

63. Brockington I, Aucamp H, Fraser C. Severe disorders of the mother-infant relationship: definitions and frequency. Arch Women Ment Health. 2006;9(5):243-51.

64. Caparros-Gonzalez RA, Romero-Gonzalez B, Strivens-Vilchez H, Gonzalez-Perez R, Martinez-Augustin O, Peralta-Ramirez MI. Hair cortisol levels, psychological stress, and psychopathological symptoms as predictors of postpartum depression. PloS one. 2017;12(8):e0182817.

65. Moher D, Shamseer L, Clarke M, Ghersi D, Liberati A, Petticrew M, et al. Preferred reporting items for systematic review and meta-analysis protocols (PRISMA-P) 2015 statement. Systematic reviews. 2015;4(1):1.

66. Stang A. Critical evaluation of the Newcastle-Ottawa scale for the assessment of the quality of nonrandomized studies in meta-analyses. Eur $\mathrm{J}$ Epidemiol. 2010;25(9):603-5.

67. Doi SA, Thalib L. A quality-effects model for meta-analysis. Epidemiology. 2008:94-100.

Page $15 / 22$ 
68. Barendregt JJ, Doi SA. MetaXL user guide. Version. 2016;4:2011-6.

69. Nyaga VN, Arbyn M, Aerts M. Metaprop: a Stata command to perform a meta-analysis of binomial data. Archives of Public Health. 2014;72(1):39.

70. Higgins JP, Thompson SG. Quantifying heterogeneity in a meta-analysis. Statistics in medicine. 2002;21(11):1539-58.

71. Liu JL. The role of the funnel plot in detecting publication and related biases in meta-analysis. Evid-Based Dent. 2011;12(4):121.

72. Gavin NI, Gaynes BN, Lohr KN, Meltzer-Brody S, Gartlehner G, Swinson T. Perinatal depression: a systematic review of prevalence and incidence. Obstetrics Gynecology. 2005;106(5):1071-83.

73. Brito CNdO, Alves SV, Ludermir AB, Araújo TVBd. Postpartum depression among women with an unintended pregnancy. Rev Saude Publica. 2015;49:33.

74. Kheirabadi G-R, Maracy M-R, Barekatain M, Casey PR. Risk factors of postpartum depression in rural areas of Isfahan Province, Iran. Arch Iran Med. 2009;12(5):461-7.

75. Robertson E, Grace S, Wallington T, Stewart DE. Antenatal risk factors for postpartum depression: a synthesis of recent literature. Gen Hosp Psychiatry. 2004;26(4):289-95.

76. Manikkam L, Burns JK. Antenatal depression and its risk factors: an urban prevalence study in KwaZulu-Natal. South African Medical Journal. 2012;102(12):940-4.

77. Organization WH. Global and regional estimates of violence against women: prevalence and health effects of intimate partner violence and nonpartner sexual violence: World Health Organization; 2013.

78. Ozbay F, Johnson DC, Dimoulas E, Morgan C III, Charney D, Southwick S. Social support and resilience to stress: from neurobiology to clinical practice. Psychiatry (Edgmont). 2007;4(5):35.

79. Saligheh M, Rooney RM, McNamara B, Kane RT. The relationship between postnatal depression, sociodemographic factors, levels of partner support, and levels of physical activity. Frontiers in psychology. 2014;5:597.

80. Urquia ML, Pulver A, Heaman MI, Ray JG, Daoud N, O'Campo P. Partner disengagement from pregnancy and adverse maternal and infant outcomes. Journal of Women's Health. 2017;26(3):234-40.

81. Patel V, Rodrigues M, DeSouza N. Gender, poverty, and postnatal depression: a study of mothers in Goa, India. Am J Psychiatry. 2002;159(1):437.

82. Anokye R, Acheampong E, Budu-Ainooson A, Obeng El, Akwasi AG. Prevalence of postpartum depression and interventions utilized for its management. Annals of general psychiatry. 2018;17(1):18.

83. Ross LE, Dennis C-L. The prevalence of postpartum depression among women with substance use, an abuse history, or chronic illness: a systematic review. Journal of Women's Health. 2009;18(4):475-86.

\section{Figures}




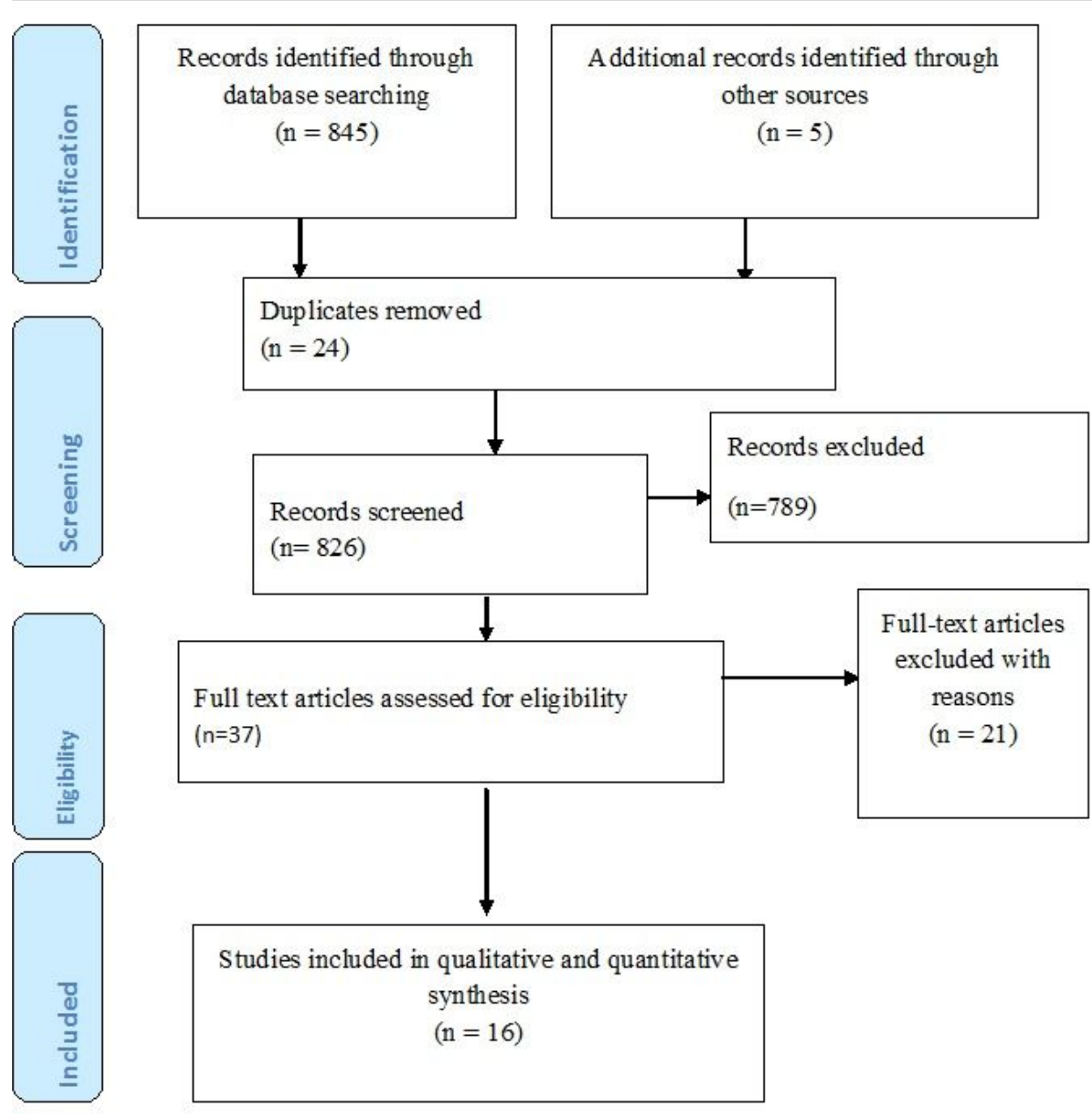

Figure 1

PRISMA flow chart for the review search process. 
Author, year of publication

ES $(95 \% \mathrm{Cl}) \quad$ Weight

\begin{tabular}{|c|c|c|c|}
\hline Fantahun et al,2018 & i & $23.30(23.11,23.49)$ & 6.25 \\
\hline Toru et al. 2018 & ; & $22.40(22.18,22.62)$ & 6.25 \\
\hline Kerieet al. 2018 & I & • $33.80(33.59,34.01)$ & 6.25 \\
\hline Bitew et al.2019 & $\uparrow$ & $22.10(21.97,22.23)$ & 6.25 \\
\hline Azale et al.2018 & * & $12.20(12.09,12.31)$ & 6.25 \\
\hline $\mathrm{G}$ gebremichael et al.2018 & ? & $22.60(22.42,22.78)$ & 6.25 \\
\hline Abadiga,muktar 2019 & 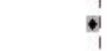 & $20.90(20.62,21.18)$ & 6.25 \\
\hline Teferra benti et al. 2015 & & - $31.50(31.27,31.73)$ & 6.25 \\
\hline Abebe et al. 2019 & 个 & $22.10(21.89,22.31)$ & 6.25 \\
\hline MM Asaye et al 2020 & & $25.00(24.80,25.20)$ & 6.25 \\
\hline Anato et al 2019 & 8 & $22.80(22.49,23.11)$ & 6.25 \\
\hline Shituet al. 2019 & & $23.70(23.51,23.89)$ & 6.25 \\
\hline W Dargie et al. 2020 & $\bullet$ & $15.60(15.29,15.91)$ & 6.25 \\
\hline JN baumgartneret al. 2014 & * & $19.80(19.66,19.94)$ & 6.25 \\
\hline Shewangizaw et al.2018 & & $13.11(12.58,13.64)$ & 6.24 \\
\hline Mariam et al. 2016 & - & $19.00(18.80,19.20)$ & 6.25 \\
\hline Overall $\left(\mathrm{I}^{2}=98 \%, \mathrm{p}=0.000\right)$ & & $21.87(18.98,24.77)$ & 100.00 \\
\hline $\begin{array}{l}\text { NOTE: Weights are from random effects } \\
\text { analysis }\end{array}$ & & & \\
\hline
\end{tabular}

Figure 2

A forest plot for the prevalence of postpartum depression in Ethiopia. 


\section{EPDS}

Fantahun et al, 2018

Kerieet al. 2018

Abadiga, muktar 2019

Abebe et al. 2019

MMAsaye et al 2020

Anato et al .2019

Shituet al. 2019

W Dargie et al. 2020

Shewangizaw et al. 2018

Mariam et al. 2016

Subtotal(I-squared $=96 \%, p=0.000$ )

\section{PHQ-9}

Toru et al. 2018

Bitew et al.2019

Azale et al.2018

Subtotal (I-squared $=99 \%, p=0.000$ )

SRQ-20

G gebremichael et al.2018

Teferra et al.2015

JN baumgartneret al. 2014

Subtotal (I-squared $=98 \%, p=0.000$ )

Overall (I-squared $=98 \%, p=0.000$ )

NOTE: Weights are from random effects analysis

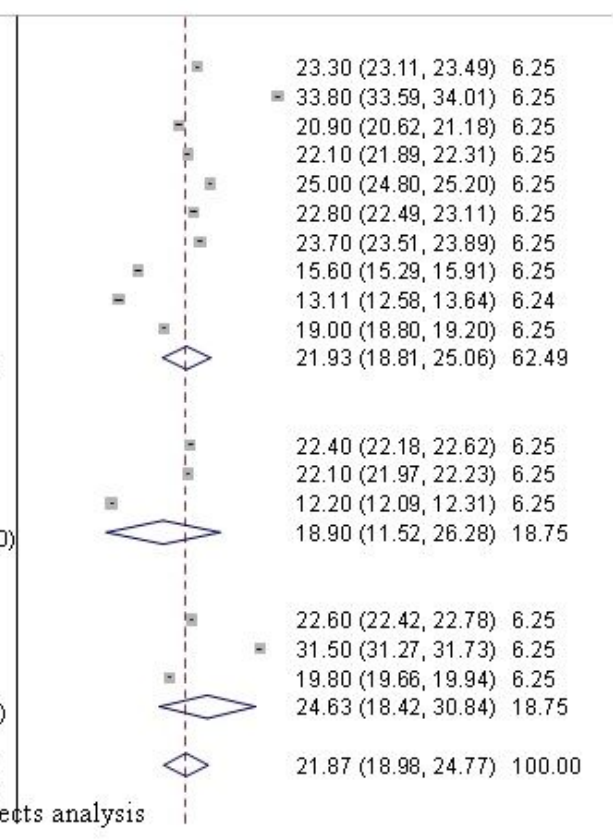

Figure 3

a forest plot for the sub-group analysis of the prevalence of postpartum depression by measurement tool used. 
Funnel plot with pseudo $95 \%$ confidence limits

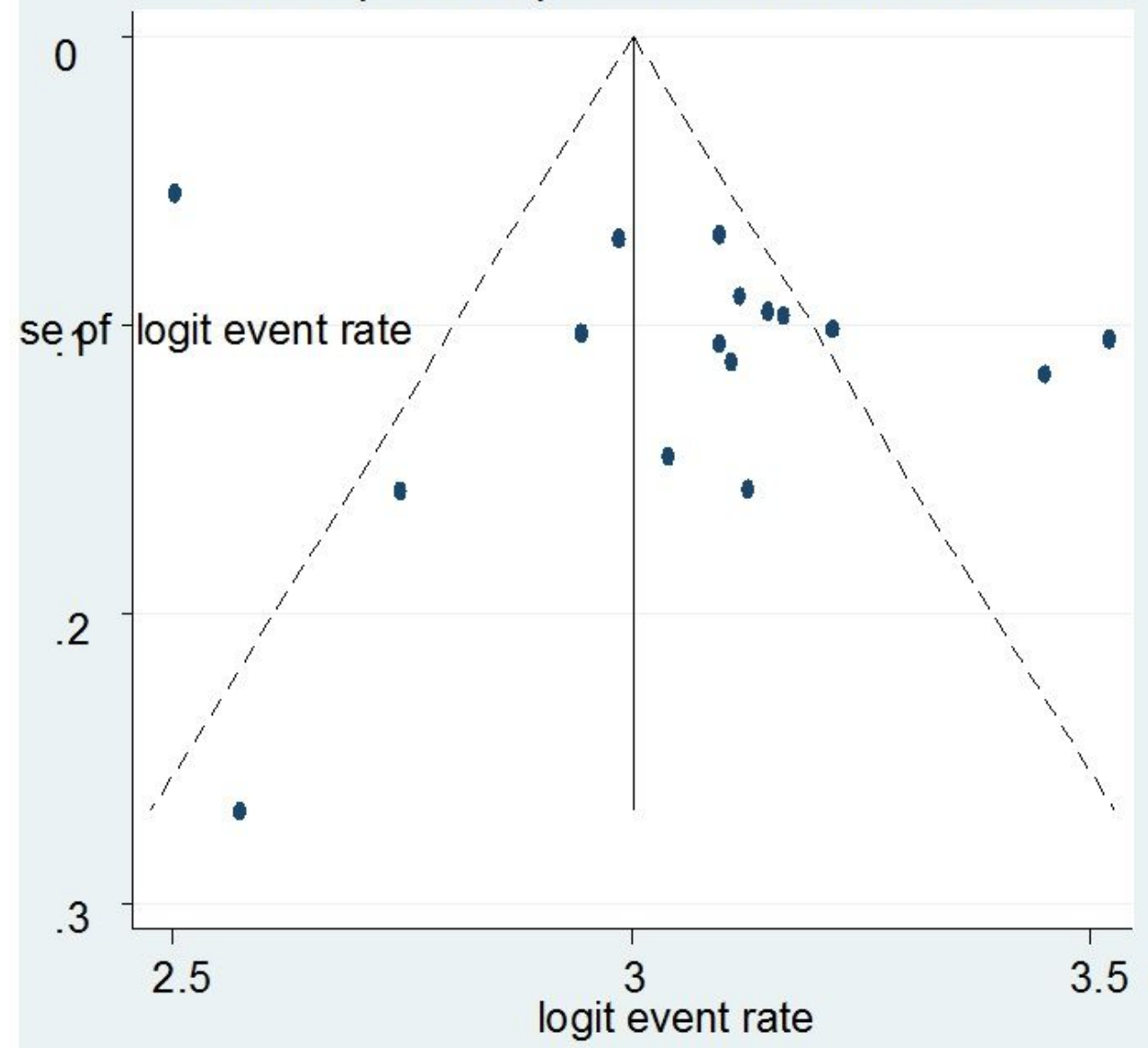

Figure 4

A funnel plot for the pooled adjusted odds ratio of poor marital relationship. 


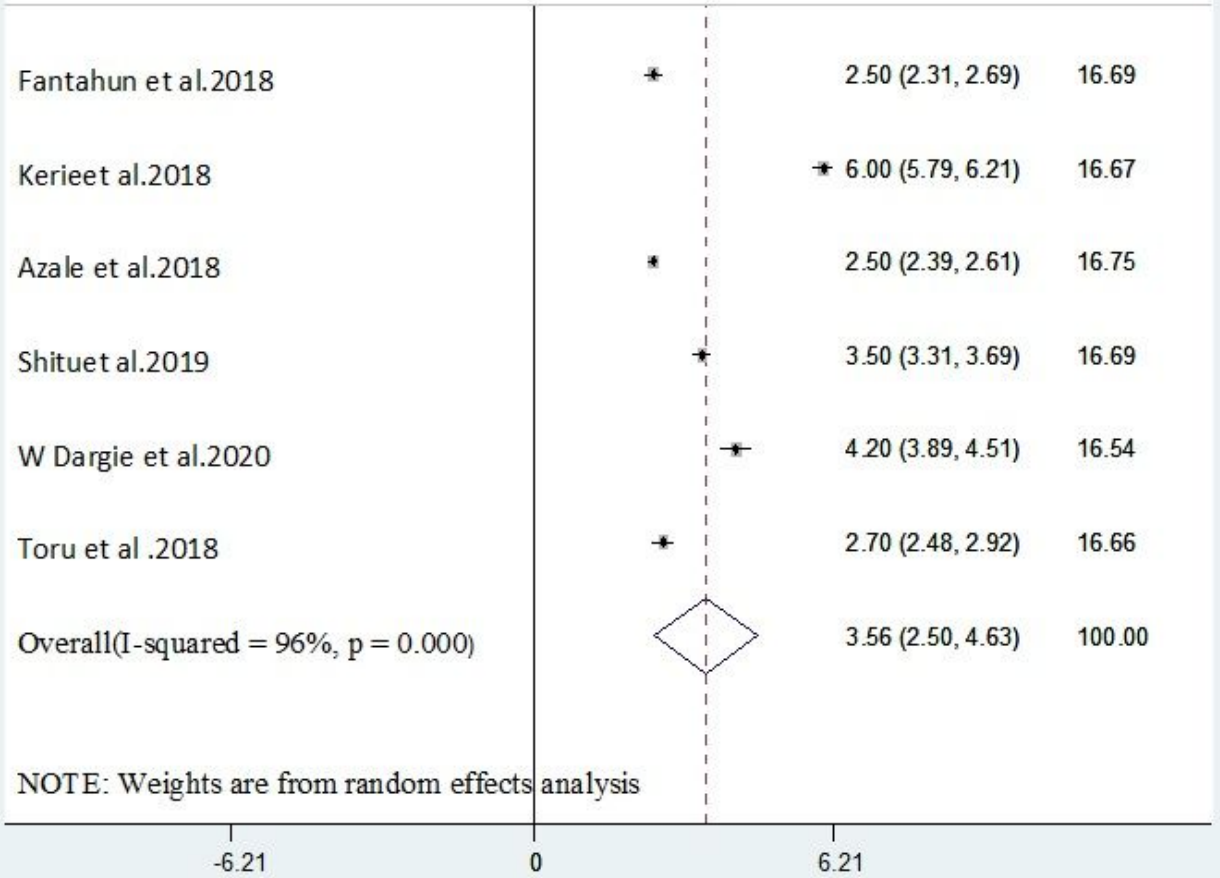

\section{Figure 5}

A forest plot for the pooled adjusted odds ratio of poor marital relationship. 
Author, year of publication

ES $(95 \% \mathrm{CI}) \quad \%$ Weight

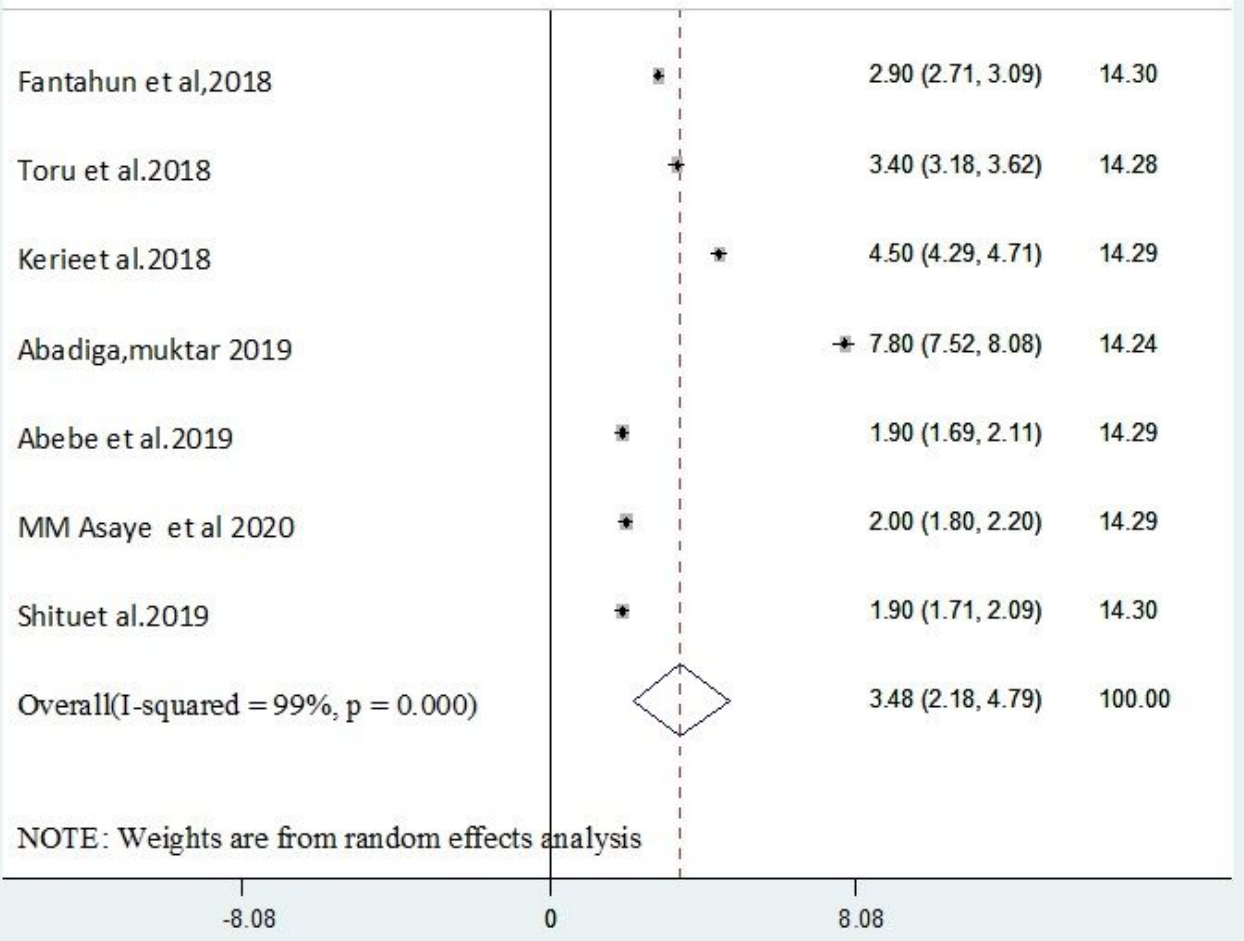

\section{Figure 6}

A forest plot for the pooled adjusted odds ratio of unplanned pregnancy.

\section{Supplementary Files}

This is a list of supplementary files associated with this preprint. Click to download.

- Additionalfile1.docx 